\title{
Electrolysis of iron in a molten oxide electrolyte
}

\author{
Jan Wiencke ${ }^{1,2} \cdot$ Hervé Lavelaine $^{1} \cdot$ Pierre-Jean Panteix $^{2} \cdot$ Carine Petitjean $^{2} \cdot$ Christophe Rapin $^{2}$
}

Received: 9 July 2017 / Accepted: 26 December 2017 / Published online: 5 January 2018

(c) The Author(s) 2018. This article is an open access publication

\begin{abstract}
Direct iron production at molten metal state from iron oxides by the sole application of electrical energy represents a possible route to decarbonize steel industry. Although chemically simple, this reaction is difficult to implement due to the problem of the multiple valence states of iron and to an operating temperature above $1811 \mathrm{~K}$. Thermal, chemical, and electrical conditions have been identified based on thermodynamic considerations to carry out this reaction in a laboratory device. Experiments were undertaken to determine the contribution of the thermal level to the decomposition of iron oxide and to estimate the electronic current resulting from iron multiple valence states. The production of liquid iron was obtained resulting in recoverable samples produced at liquid state and from a faradaic process checked in real time by its accompanying anodic oxygen evolution.
\end{abstract}

\section{Graphical Abstract}
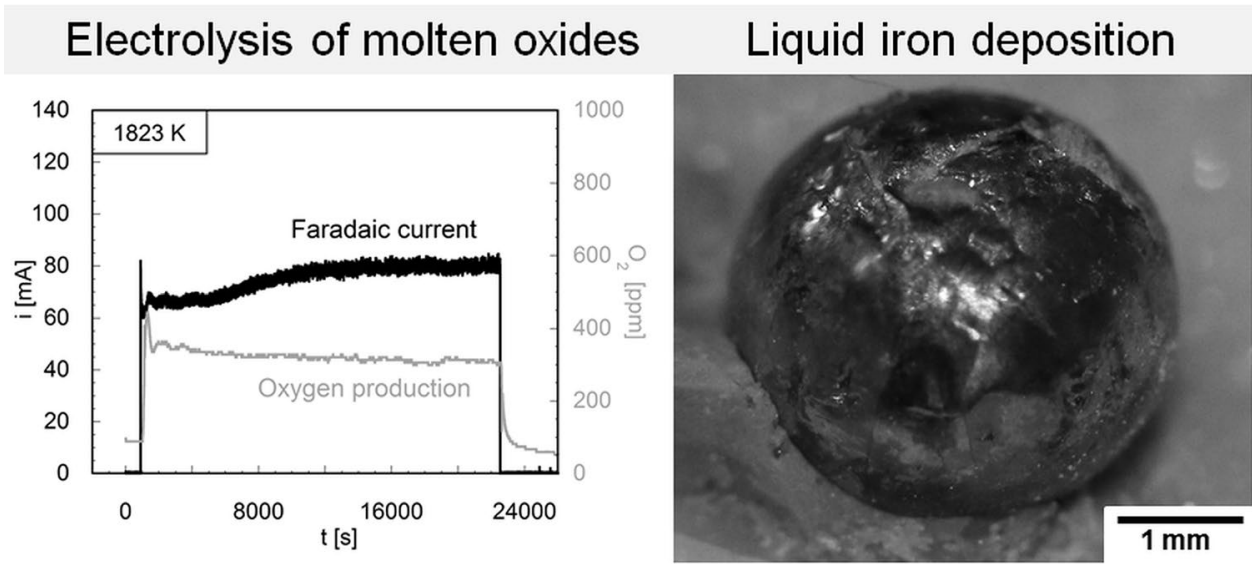

Keywords Molten oxide electrolysis $\cdot$ Metal extraction $\cdot$ Oxide melts $\cdot$ Electrochemical engineering $\cdot$ High-temperature processing

\section{Introduction}

Jan Wiencke

Jan.wiencke@arcelormittal.com

1 Ironmaking, Maizières Process, Global Research and Development ArcelorMittal, Voie Romaine, B.P. 30320, 57283 Maizières-lès-Metz Cedex, France

2 IJL-UMR 7198, Départment CP2S, Equipe 206 (Surface et Interface: Réactivité Chimique des Matériaux), B.P. 70239, 54506 Vandœuvre-lès-Nancy Cedex, France
Climate change represents one of the biggest problems faced by carbon dioxide emitting industrial activities. World steel industry is responsible for emissions of more than 2 billion tons of carbon dioxide per year $[1,2]$. To reduce these emissions, the ULCOS research program (2004-2012) was launched to evaluate alternative techniques to cut down this vast amount of emission of greenhouse gases [3]. One of the possible routes is molten iron by direct electrolysis of iron 
ore (MIDEIO). The concept is inspired from developments on the production of oxygen gas on the moon [4] and was later reconsidered for metal production [5-8]. It offers attractive advantages, such as the production of liquid, chemically pure iron, and without direct emission of $\mathrm{CO}_{2}$. Recently, a comprehensive review on the prospects of electrolytic metal production was published, highlighting the process's perspective and industrial potential [9].

Today, massive metal production following this route represents a substantial part in metal industry, e.g., the Hall-Héroult technology for aluminum metal [10]. However, straightforward application of the underlying concepts in terms of electrolyte composition and electrode materials can hardly be considered for iron production. Indeed, iron has a significantly higher liquidus temperature and is considered unsuitable to electrochemical treatments due to the multiple valence states of its ions. The first constraint requires highly demanding properties for the cell materials and the second causes a low faradaic yield.

In the present study, these shortcomings are addressed following thermodynamic considerations to identify suitable solutions for MIDEIO development. Accordingly, an experimental device is proposed to carry out the reaction at laboratory scale at temperature above $1811 \mathrm{~K}$.

$\frac{1}{3} \mathrm{Fe}_{3} \mathrm{O}_{4}(\mathrm{~s}) \rightleftarrows \mathrm{Fe}(\mathrm{l})+\frac{2}{3} \mathrm{O}_{2}(\mathrm{~g}, 1 \mathrm{~atm})$

The first objective is to check that the faradaic reduction of iron is possible at very high temperature. The second is to identify the electrochemical processes taking place at each electrode by analyzing results regarding the overall charge balance of the cell.

\section{Determination of chemical and electrical conditions to decompose iron oxides}

\subsection{Formulation of an electrolyte composition to carry out MIDEIO}

The first imperative condition of MIDEIO is to operate above liquidus temperature of iron metal, which is $1811 \mathrm{~K}$ $[11,12]$. In the following, the selected operating temperature is $1823 \mathrm{~K}$. The source of iron oxide for this process is supposed to come from naturally occurring iron ores. These are mainly present as hematite, $\mathrm{Fe}_{2} \mathrm{O}_{3}$, a mineral stable at ambient temperature and atmospheric partial pressures of oxygen $[13,14]$. At temperatures above $1688 \mathrm{~K}$, hematite decomposes spontaneously into magnetite and oxygen gas $[15,16]$.

$6 \mathrm{Fe}_{2} \mathrm{O}_{3}(\mathrm{~s}) \rightleftarrows 4 \mathrm{Fe}_{3} \mathrm{O}_{4}(\mathrm{~s})+\mathrm{O}_{2}(\mathrm{~g}, 1 \mathrm{~atm})$
The stability of magnetite indicates that iron oxide is composed of both ferrous and ferric iron at the considered electrolysis temperature. The combination of these two ions is a major obstacle to implement electrochemical reactions as the electrical current flows by electronic conduction with electrons hopping from one valence state to another [17]. To guarantee ionic conduction and accompanying electrochemical reactions at the electrodes, a chemical environment must be chosen to favor one of the valence states in order to decrease to vanishingly low values electronic conductance. To characterize the relative prevalence of these valence states, the ferric ratio is defined as the relative amount of ferric iron:

$\mathrm{Fe}^{3+}=\frac{\mathrm{Fe}^{3+}}{\mathrm{Fe}^{2+}+\mathrm{Fe}^{3+}}$,

where $\mathrm{Fe}^{2+}$ and $\mathrm{Fe}^{3+}$ denote in this formula the molar concentrations.

The phase diagram showing the domains of stability of iron oxides according to temperature and oxygen partial pressure is presented in Fig. 1 [18]. The general trend is toward lowering the oxidation state of iron with lower oxygen partial pressure and with higher temperature. It shows also that liquid iron is in equilibrium with wüstite and oxygen with magnetite at high temperatures. Both equilibria define the electrodes reaction. Clearly, the thermal conditions during MIDEIO are too high to consider a ferric ratio close to unity. Hence, the chemical environment must

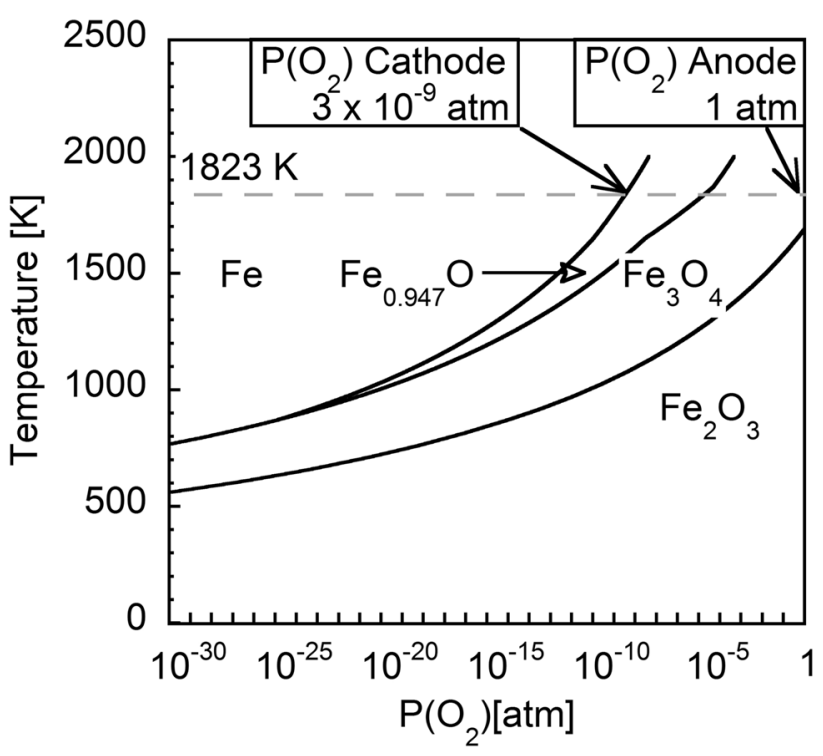

Fig. 1 Fe-O Phase diagram and definition of cathodic and anodic conditions, "cathode" represents the equilibrium of metallic iron with wüstite, which is at $1823 \mathrm{~K}$ defined by a $\mathrm{P}\left(\mathrm{O}_{2}\right)$ of $3 \times 10^{-9} \mathrm{~atm}$. "Anode" represents the equilibrium of oxygen at atmospheric pressure with magnetite [18] 


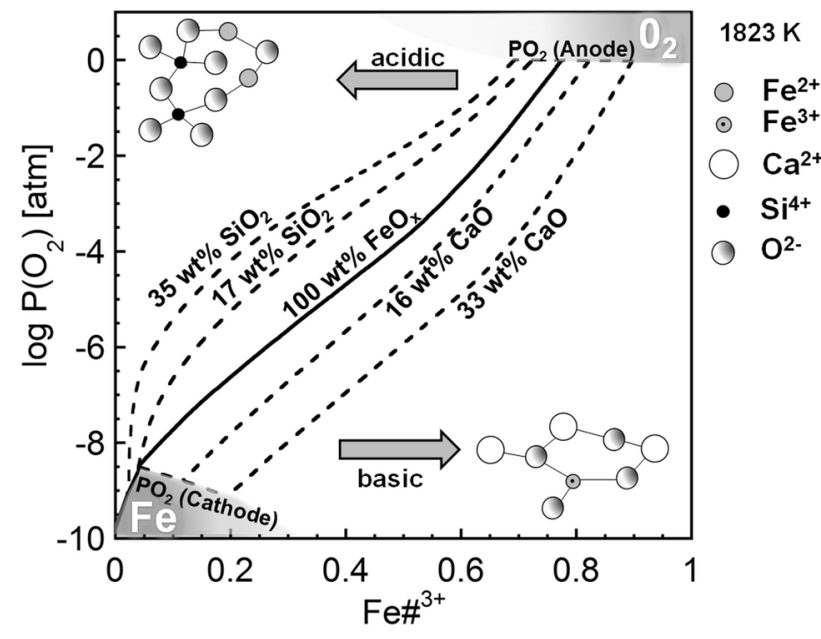

Fig. 2 Dependence of $\mathrm{P}\left(\mathrm{O}_{2}\right)$ on the ferric ratio for iron oxide dissolved in silica or lime at $1823 \mathrm{~K}$ [19]

be changed to decrease the ferric ratio to vanishing low values. To this respect, the effects of acidity by dilution of iron oxides in silica and of basicity by dilution in lime are represented on Fig. 2 [19] in dependence of oxygen partial pressure $\mathrm{P}\left(\mathrm{O}_{2}\right)$. Acidic conditions lower the ferric ratio due to the increasing polymerization of the network of the molten oxide $[19,20]$. Conversely, basic conditions depolymerize the network, allowing thereby the stabilization of ferric iron by incorporation in higher proportions $[21,22]$. This effect is illustrated by the two sketches in Fig. 2, showing the incorporation of the different cations in the electrolyte structure. It becomes apparent that the choice of a silica-based electrolyte with a low concentration of iron oxide can achieve a very low ferric ratio in the reducing conditions of the cathode. Thus, a silica-based electrolyte is selected to continue the formulation of an electrolyte composition.

For practical implementation of the MIDEIO route, additional properties of the electrolyte are required:

1. The electrolyte composition must be compatible with the refractory material chosen for the crucible to avoid or to minimize its chemical dissolution.

2. The electrolyte must be in the liquid state in order that oxygen gas separates as bubbles by buoyancy from the electrolyte.

3. Other constituents of the electrolyte must be less reducible than the iron oxides.

Alumina was chosen as the refractory material for the crucible, since it is known to withstand high temperatures and a large range of $\mathrm{P}\left(\mathrm{O}_{2}\right)$ [23]. Thus, an electrolyte composition close to alumina saturation is necessary to avoid the refractory's chemical dissolution.
Regarding the second requirement of the electrolyte, its liquid state is guaranteed by a superheat of $100 \mathrm{~K}$ between the operating temperature and the liquidus of the iron-free electrolyte. Since the operation temperature is $1823 \mathrm{~K}$, liquidus temperature of the electrolyte has not to surpass $1723 \mathrm{~K}$. Therefore, alumina and magnesia were added to silica. The resulting composition is named here Fe\#0. Its oxide proportions are displayed in Table 1. This composition offers a sufficiently low liquidus temperature of $1540 \mathrm{~K}$ while being close to the alumina saturation limit at $1823 \mathrm{~K}$ [24].

To account for the third property, the decomposition voltages of silica, alumina and magnesia are compared to those of magnetite and iron monoxide. Oxides were considered as pure compounds in their standard state and the results neglect the dissolution effects. The corresponding free enthalpy energy, partial pressure of oxygen in equilibrium with the reduced product, and potential difference $\left(\Delta E^{\circ}\right)$ are presented in Table 2. These parameters are related by the following relation:

$\Delta G^{\circ}=-R T \ln \left[\mathrm{P}_{\mathrm{O}_{2}}\right.$ (cathode) $]=n F \Delta E^{\circ}$,

where $n$ is the number of electrons, $F$ Faraday's constant in $\mathrm{C} \mathrm{mol}^{-1}, R$ the universal gas constant in $\mathrm{J} \mathrm{mol}^{-1} \mathrm{~K}^{-1}$, and $T$ the temperature in $\mathrm{K}$.

The derived values show that iron is indeed preferentially decomposed by electricity compared to the other constituents of the electrolyte. It suggests also that an operating window may exist where iron could be selectively reduced.

\subsection{Formulation of an iron oxide concentration to carry out MIDEIO}

Finally, thermodynamic calculations were carried out with the thermo-chemical software CECQSI [25] to take into account the effect of the chemical dissolution of iron oxide in the proposed electrolyte composition. A concentration of $15 \%$ in weight of iron oxide, named in Fe\#15, has been selected. The variation of the ferric ratio in this composition from equilibrium with liquid iron to equilibrium with oxygen at atmospheric pressure is shown in Fig. 3. The ferric ratio at the anode is the result of the thermal decomposition and of the dilution in the silicabased medium of the original hematite compound. The

Table 1 Composition and properties of electrolytes used for experiments

\begin{tabular}{llllll}
\hline & $\begin{array}{l}\mathrm{SiO}_{2} \\
(\mathrm{wt} \%)\end{array}$ & $\begin{array}{l}\mathrm{Al}_{2} \mathrm{O}_{3} \\
(\mathrm{wt} \%)\end{array}$ & $\begin{array}{l}\mathrm{MgO} \\
(\mathrm{wt} \%)\end{array}$ & $\begin{array}{l}\mathrm{Fe}_{3} \mathrm{O}_{4} \\
(\mathrm{wt} \%)\end{array}$ & Liquidus $^{\mathrm{a}}$ \\
\hline Fe\#0 & 66 & 20 & 14 & - & $1540 \mathrm{~K}$ \\
\hline
\end{tabular}

${ }^{\mathrm{a} C a l c u l a t e d}$ with CEQCSI [25] 
Table 2 Conceivable reactions in used electrolytes and their corresponding free enthalpy, partial oxygen pressures, and potential difference at $1823 \mathrm{~K}$ [26]

\begin{tabular}{lllll}
\hline & Reaction & $\Delta G^{\circ}\left(\mathrm{kJ} \mathrm{mol}^{-1}\right)$ & $\begin{array}{l}\text { Log } \mathrm{P}\left(\mathrm{O}_{2}\right) \text { cathode } \\
(\mathrm{atm})\end{array}$ & $\Delta E^{\circ}(\mathrm{V})$ \\
\hline$(4)$ & $1 /{ }_{2} \mathrm{Fe}_{3} \mathrm{O}_{4}(\mathrm{~s}) \rightleftarrows{ }^{3} /{ }_{2} \mathrm{Fe}(\mathrm{l})+\mathrm{O}_{2}(\mathrm{~g})$ & 273 & -8 & 0.71 \\
$(5)$ & $2 \mathrm{FeO}(\mathrm{l}) \rightleftarrows 2 \mathrm{Fe}(\mathrm{l})+\mathrm{O}_{2}(\mathrm{~g})$ & 316 & -9 & 0.82 \\
$(6)$ & $\mathrm{SiO}_{2}(\mathrm{~s}) \rightleftarrows \mathrm{Si}(\mathrm{l})+\mathrm{O}_{2}(\mathrm{~g})$ & 586 & -17 & 1.52 \\
$(7)$ & $2 \mathrm{SiO}_{2}(\mathrm{~s}) \rightleftarrows 2 \mathrm{SiO}(\mathrm{g})+\mathrm{O}_{2}(\mathrm{~g})$ & 660 & -19 & 1.72 \\
$(8)$ & $2 \mathrm{MgO} \mathrm{s}) \rightleftarrows 2 \mathrm{Mg}(\mathrm{g})+\mathrm{O}_{2}(\mathrm{~g})$ & 711 & -20 & 1.84 \\
(9) & $2 /{ }_{3} \mathrm{Al}_{2} \mathrm{O}_{3}(\mathrm{~s}) \rightleftarrows{ }^{4} /{ }_{3} \mathrm{Al}(\mathrm{l})+\mathrm{O}_{2}(\mathrm{~g})$ & 727 & -21 & 1.88
\end{tabular}

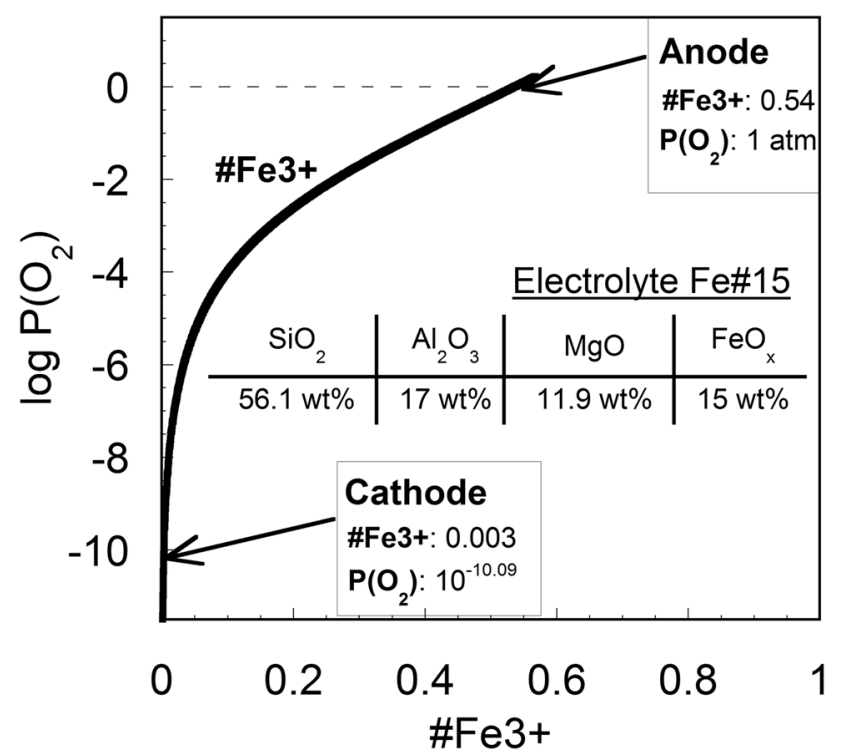

Fig. 3 Dependence of $\mathrm{P}\left(\mathrm{O}_{2}\right)$ on the ferric ratio in the selected electrolyte composition \#Fe15 at $1823 \mathrm{~K}$

Table 3 Decomposition potentials of iron oxides in the Fe\#15 melt at $1823 \mathrm{~K}$ and $\mathrm{P}\left(\mathrm{O}_{2}\right)$ of $1 \mathrm{~atm}$

\begin{tabular}{lll}
\hline & Reaction & $\Delta E^{\circ}(\mathrm{V})$ \\
\hline (11) & $0.425 \mathrm{Fe}_{3} \mathrm{O}_{4}+0.3 \mathrm{FeO} \rightleftarrows 1.575 \mathrm{Fe}(\mathrm{l})+\mathrm{O}_{2}(\mathrm{~g}, 1 \mathrm{~atm})$ & 0.91 \\
\hline
\end{tabular}

corresponding stoichiometry of the reaction of decomposition of the iron oxide, Eq. (11), is presented in Table 3.

For a successful iron electrolysis, it must be ensured that the concentration of iron oxide is large enough to maintain a low decomposition voltage (Table 3 ) and is low enough to guarantee a small ferric ratio close to the cathode (Fig. 3). It has been checked that the liquidus temperature conforms to the requirements with a value of $1594 \mathrm{~K}$.

\section{Experimental plan}

The purpose of the experiments is to prove that an electrochemical route can be designed to supply electrical energy to the reaction of iron oxide decomposition Eq. (11). To ensure that metal iron production results from a faradaic phenomenon, the contribution of the thermal level to iron oxide decomposition and electronic current in the electrolyte must be evaluated.

The first step is to measure the influence of the thermal level on the oxygen evolution. Then, an electrochemical driving force as a voltage must be chosen to guarantee the quantitative production of iron. For this purpose, stepped linear scanning voltammetry is applied between anode and cathode to identify the conditions of significant electrical current flow. Finally, this cell voltage is applied during long lasting experiments in order to produce an iron sample that can be analyzed afterwards.

\section{Materials and methods}

\subsection{Experimental set-up}

Electrolytes were prepared from oxide powders and mixed manually. Iron, introduced as magnetite (grain size $\leq 5 \mu \mathrm{m}$, Aldrich, purity 98\%) and magnesia (ACROS, purity 99\%) were added in powder form ( $\mu \mathrm{m}$-scale), while alumina (ACROS, purity 98\%) and silica (grain size $\leq 1 \mathrm{~mm}$, ACROS) were added as grains (mm-scale). Iron oxide powder was confirmed as magnetite with XRD analysis.

The base of the experimental set-up was constituted by a vertical tube furnace with a maximum temperature of $2073 \mathrm{~K}$ (Fig. 4a) in which the experimental set-up to perform MIDEIO is placed (Fig. 4b). Water cooling connected to the steel caps at the ends of the alumina tube provides gas tightness of the system and enables the use of conventional electrical connections. During trials, the tube was flushed with a steady flow of argon gas (Westfalen, Ar: 99.998\% $\mathrm{O}_{2}: 3 \mathrm{ppm}$ ), which was measured by a flow meter before its entrance into the furnace providing a controlled atmosphere. Oxygen gas leaving the furnace was analyzed with a 


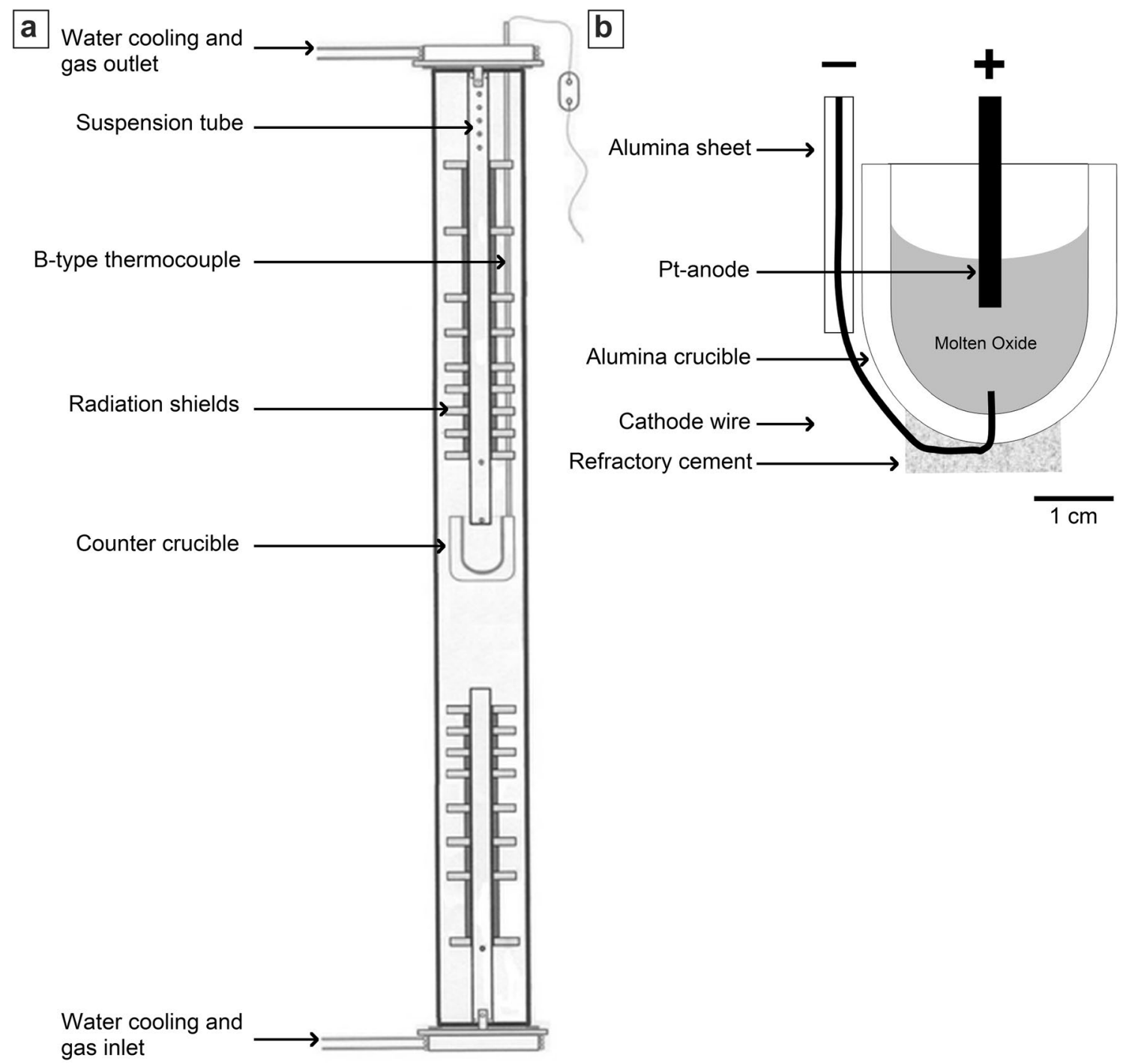

Fig. 4 Schematic drawing of the experimental set-up. a Assemblage in tube furnace (not to scale), tube height: $150 \mathrm{~cm}$, outer tube diameter: $8.6 \mathrm{~cm}$. b Electrolysis cell

gas analyzer (Systech, Model 911). The electrolysis cell was placed in the isothermal region of the tube furnace with a self-made sample holder (upper part inside the ceramic tube in Fig. 4a). Additionally, the aperture was used to introduce electrodes and a B-type thermocouple (Pt-Pt30\%Rh) to the system. A micrometer on top of the sample holder allowed positioning within $1 \mathrm{~mm}$ precision of the anode inside the cell regarding its distance to the cathode.

The electrolysis cell itself, shown in Fig. 4b, consisted of a cylindrical alumina crucible with a round-shaped bottom. To capture the produced iron, using the difference in density of electrolyte and liquid iron, electrodes were configured vertically.

The chosen anode material has to resist high oxygen pressure, a temperature of $1823 \mathrm{~K}$ and offer a high electrical conductivity. Most materials oxidize rapidly, restricting thereby the material choice to noble metals. For this approach, $\mathrm{Pt}$ was taken, being known for its stable performance under comparable conditions [27]. To allow a sufficient mechanical strength and penetration into the electrolyte, the anode was a rod with a diameter of $3 \mathrm{~mm}$.

Similar requirements are met for the cathode material, taking into regard the difference in oxygen partial pressure. Additionally, the production and deposition of iron are taking place at the cathode and an alloying of deposit with electrode is expected. Again, platinum offers good properties as it is highly conductive and does not participate in the electrochemical reaction. However, rapid alloying of iron and pure Pt might corrupt the mechanical properties [28]. To counteract this process, an alloy of platinum and rhodium (30\%) was taken, which should increase the physical stability of the cathode wire, which had a diameter of $1 \mathrm{~mm}$. It was introduced into 
the cell via a hole in the bottom of the alumina refractory, which was then sealed with one component alumina cement 989 (CotronicsCorp.).

\subsection{Experimental conditions and characterization methods}

Experiments were conducted at a temperature of $1823 \mathrm{~K}$ for minimum $6 \mathrm{~h}$ in argon atmosphere. A gas flow rate of $0.05 \mathrm{~m}^{3} \mathrm{~h}^{-1}$ was adjusted under standard conditions (STP), which are defined for atmospheric pressure and temperature at $273 \mathrm{~K}$. Heating was done by a multi-step ramp, which was programmed with dwelling times at intermediate temperatures and slow ramps. This was done to avoid foaming during melting due to a release of oxygen gas during decomposition of iron oxides following Eq. (2).

Electrolysis was conducted once for the Fe\#0 composition and twice for the Fe\#15, to show its reproducibility: they are referred here as trial (A) and trial (B). Within these three trials, a constant cell voltage of $3 \mathrm{~V}$ was applied for $6 \mathrm{~h}$. In all experiments, the cell was let inside the furnace to cool down naturally, which led to a partial crystallization of the electrolyte.

Application of voltage for each electrolyte composition was done via electrochemical analysis using a VersaStat 3 (Ametek). Open-circuit measurements and stepped linear scan voltammetry in the range of $0-4 \mathrm{~V}$ were programed with the software VersaStudio 2.41.2. For the stepped linear scan voltammetry, $100 \mathrm{mV}$ steps were programed with a dwell time of $10 \mathrm{~min}$, resulting in a scanning rate of $0.15 \mathrm{mV} \mathrm{s}^{-1}$. Values used for further calculation were obtained for each cell voltage by taking the average of the second half of each cell voltage increment.

Cross-section observations were done via scanning electron microscopy (SEM) using a JEOL JSM-6010LA equipped with a tungsten filament. Quantitative analysis was performed with an energy-dispersive spectrometer (EDS) installed on the SEM. For the analysis, the sample of the first electrolysis trial (A) was crushed with a hammer to extract the produced deposit. This was put in a conductive resin, subsequently polished (finishing grade: $1 \mu \mathrm{m}$ with diamond solution) and finally analyzed using $20 \mathrm{kV}$ electron beam. In addition, the entire cell of the second electrolysis trial (B) was embedded in a translucent resin and then cut with a diamond saw in two halves for demonstration of the cell structure.

\section{Experimental results}

\subsection{Determination of the thermally generated oxygen level in the experimental set-up}

As $\mathrm{Fe}_{3} \mathrm{O}_{4}$ was introduced as starting material, decomposition due to thermal level and to the low $\mathrm{P}\left(\mathrm{O}_{2}\right)$ will occur.
This thermal generation of oxygen gas has to be separated from the faradaic reactions and thus the sole action of temperature on the electrolytes at operating conditions was quantified. Therefore, oxygen levels in the gas atmosphere were measured for both electrolyte compositions in opencircuit trials at the prescribed temperature for $6 \mathrm{~h}$. The resulting signals are presented in Fig. 5.

The atmosphere of the Fe\#0 composition showed a constant level of oxygen corresponding to the minimum value of the data logger. A trend in the data over the experimental duration was not visible. Since Ar gas used here exhibits 3 ppm $\mathrm{O}_{2}$, the assemblage can be regarded as gas tight. The set-up was chosen to prevent any possibility of a chemical reduction of iron oxide to its metallic state. All parts implemented are known for their non-reactivity with iron oxide and their stability in the applied conditions. This was confirmed by the low values of oxygen measured during operation of the furnace with the Fe\#0, thereby proving the absence of unwanted redox reactions in the cell.

The trial conducted with Fe\#15 exhibited an oxygen level which was continuously decreasing with ongoing experimental duration. This oxygen production corresponds to the progress of the reduction of trivalent to bivalent iron, according to Reaction (2).

Therefore, the operating voltage for MIDEIO has to be chosen in order that the resulting current and oxygen level generated by faradaic reactions at the anode are significantly higher compared to the thermally generated oxygen gas identified above. This supposes to study the influence of voltage on oxygen rate production in this particular system which can be obtained by linear scanning voltammetry.

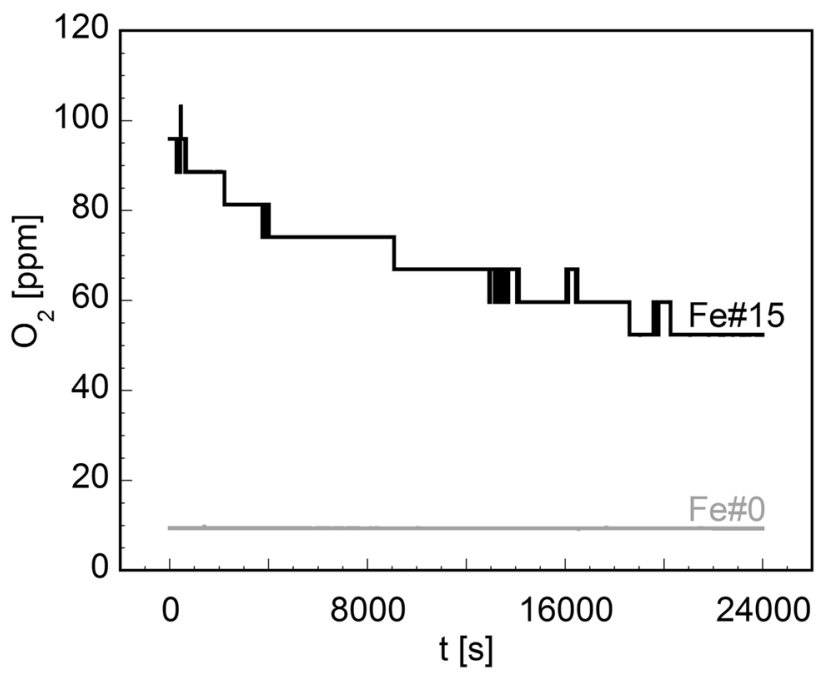

Fig. 5 Measurement of furnace atmosphere. Temperature: $1824 \mathrm{~K}$ $( \pm 3)$, gas flow: $0.05 \mathrm{STP}^{3} \mathrm{~h}^{-1}$ 


\subsection{Electrochemical reactivity and identification of reactions according to cell voltage}

Linear scan voltammetry was performed in both electrolytes (Fig. 6) to characterize their electrochemical reactivity and to identify voltage threshold of the redox couples therein. For the Fe\#0 composition, the linear scan current signal before $1 \mathrm{~V}$ was negligibly small (Fig. 6a). A significant linear increase in current was observed above $1.2 \mathrm{~V}$. Oxygen production was not noticed below a cell voltage of $1.6 \mathrm{~V}$ (Fig. 6b) and above this value it was increasing linearly with the cell voltage. In this domain, correlation of current and oxygen indicates a transfer of charge associated with faradaic reactions. The results define the onset of silica redox reaction according to Reaction (6) at a cell voltage of $1.6 \mathrm{~V}$ which corresponds approximatively to the theoretical value of $1.52 \mathrm{~V}$.

In the linear scan voltammetry with the composition Fe\#15 (Fig. 6a), a low current with a linear dependence to cell voltage (up to $1 \mathrm{~V}$ ) was observed and may indicate the contribution of electronic conduction in the molten oxide. At $1 \mathrm{~V}$, it was overlain by a large amount of current which shows a higher sensibility to the increasing cell voltage. It can be ascribed to iron oxide decomposition following Reaction (11) which is characterized by a theoretical minimum voltage of $0.91 \mathrm{~V}$ in composition Fe\#15. This faradaic reaction was confirmed by the simultaneous onset of oxygen production which augmented linearly with further cell voltage increase (Fig. 6b). The distinction of the thermally generated oxygen gas level and the oxygen gas linked to the faradaic reaction is indicated by the hachured areas in Fig. 6b.

Comparison of these two linear scans shows a significant difference in current values for equivalent cell voltages. This difference is indicative of the strong effect of the iron addition on lowering the thermodynamic threshold, on increasing the electrical conductivity and on the kinetics of faradaic reactions. From curves in Fig. 6a, the thermodynamic reduction potential can be obtained by linear regression of current to null current. Only cell voltages values measured above $1.2 \mathrm{~V}$, which correspond to the domain of oxygen gas production, are considered. The reduction potential deduced by this method is $1.03 \mathrm{~V}$. The linear correlation of current and cell voltage proves the absence of a rate limiting phenomena under the chosen conditions.

To quantify the contribution of the electronic current, the current values obtained below a cell voltage of $1 \mathrm{~V}$ were linearly extrapolated. This approach is based on the assumption that the electron transfer via the electron hoping between the two valence states of iron is following Ohm's law and has no thermodynamic threshold, thus, current and cell voltage are linearly correlated. At a cell voltage of $3 \mathrm{~V}$ it is $9 \mathrm{~mA}$, being $11 \%$ of the total current at this cell voltage and small enough to anticipate a significant contribution of faradaic reactions on the cathode (marked in Fig. 6a as EC).

The operating voltage to carry out electrolysis was chosen for an oxygen production rate significantly larger than thermal generation. A level of $300 \mathrm{ppm}$ (using a flow rate of $0.05 \mathrm{~m}^{3} \mathrm{~h}^{-1}$ ) checks this condition and corresponds to a cell voltage of $3 \mathrm{~V}$ and to a current of $80 \mathrm{~mA}$, in Fig. 6 marked as OV.

\subsection{Long-time stability of the current to oxygen correspondence}

The Fe\# 0 was subjected to these electrical conditions during a long-lasting time of $6 \mathrm{~h}$. Figure 7a shows the electrolysis trial of the Fe\#0 composition. Maximum values of current were around $35 \mathrm{~mA}$ directly at the onset of electrolysis. Within a few seconds, the current decreased to values below $25 \mathrm{~mA}$. Although being somewhat stable, a continuous decrease to values varying between 15 and $10 \mathrm{~mA}$ was then observed. Values measured for oxygen were at the beginning

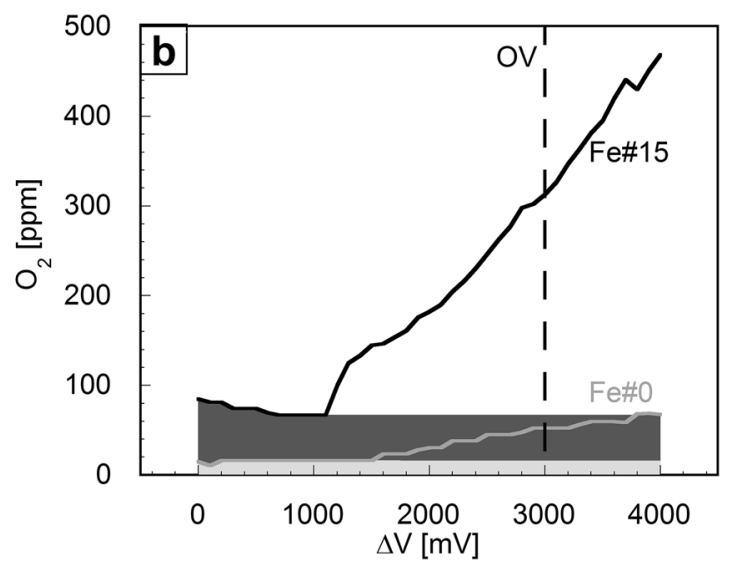

Fig. 6 a Current evolution, b oxygen evolution in linear scan measurements of both electrolytes, dotted line in a indicates the extrapolated electronic current, temperature: $1824 \mathrm{~K}( \pm 3)$, gas flow: $0.05 \mathrm{STP} \mathrm{m}^{3} \mathrm{~h}^{-1}$; scanning rate: $0.015 \mathrm{mV} \mathrm{s}^{-1}$, range of cell voltage: $0-4 \mathrm{~V}$ 
at $9 \mathrm{ppm}$ and increased shortly after the application of the cell voltage to $50 \mathrm{ppm}$ for $100 \mathrm{~min}$. Thereafter, they continuously decreased over the remaining time of electrolysis to values close to $45 \mathrm{ppm}$.

Visual characterization of the sample shows a formless dark gray deposit around the cathode $\mathrm{Pt} / \mathrm{Rh}$ wire, which cannot be detached from the solidified electrolyte. Figure $7 \mathrm{~b}$ shows the contact area of the cathode and the solidified electrolyte. Bright areas around the electrode position are parts of the cathode deposit. Their composition was identified by EDS as silicon and aluminum metal (Fig. 7c). Metal state was determined by the absence of oxygen in the deposit. Its quantity could not be determined as the sample was too small for a proper preparation.

Results of this procedure have shown that cell voltage application for a duration of $6 \mathrm{~h}$ does not change the electrochemical reactivity of the electrolyte and neither its oxygen production rate. Even though the electrolyte proved electrochemically reactive under the application of this cell voltage, its current is low and stable enough to study the effect of the iron oxide in the next experiments.
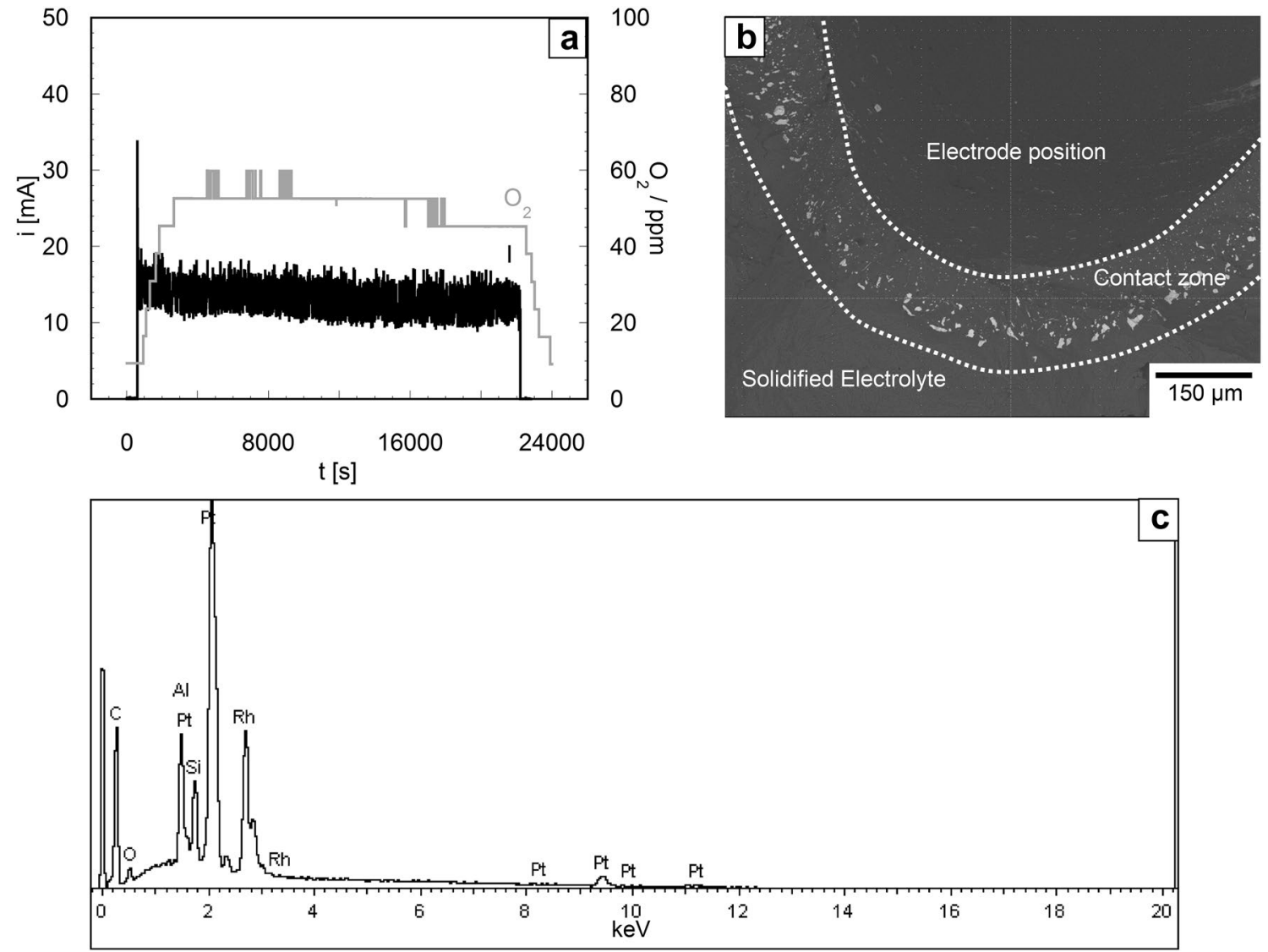

Fig. 7 Electrolysis of Fe\#0 composition. a Current response and the measured $\mathrm{O}_{2}$ in ppm. The hachured area represents the thermally generated $\mathrm{O}_{2}$ as derived from linear interpolation of the $\mathrm{O}_{2}$ ppm level before and after the electrolysis. b Back scattering electron (BSE)

\subsection{Production of iron metal via electrolysis}

Electrolysis of the Fe\#15 composition was done twice to demonstrate the reproducibility of the experiment. Obtained current and oxygen signals for each trial are plotted in Fig. 8a, b. In both cases, a steady current signal (trial (A): $65 \mathrm{~mA}$, trial (B): $80 \mathrm{~mA}$ ) was obtained for approximately $80 \mathrm{~min}$. Thereafter continuous increases were observed in the following $100 \mathrm{~min}$ to values around 80 and $90 \mathrm{~mA}$, respectively. At these levels, current signals remained constant until the cell voltage application was stopped.

Before the cell voltage application, oxygen concentrations in the analyzed gas were around $90 \mathrm{ppm}$. Shortly after the start of electrolysis, concentration of oxygen augmented quickly in both trials, leading to a peak at 500 and $450 \mathrm{ppm}$, respectively. Thereafter, a steady decrease to levels of $300 \mathrm{ppm}$ during the remaining experimental duration was observed. The oxygen signal stabilized at $52 \mathrm{ppm} 60 \mathrm{~min}$ after the electrolysis, revealing a decrease of the thermally generated oxygen level over the whole 


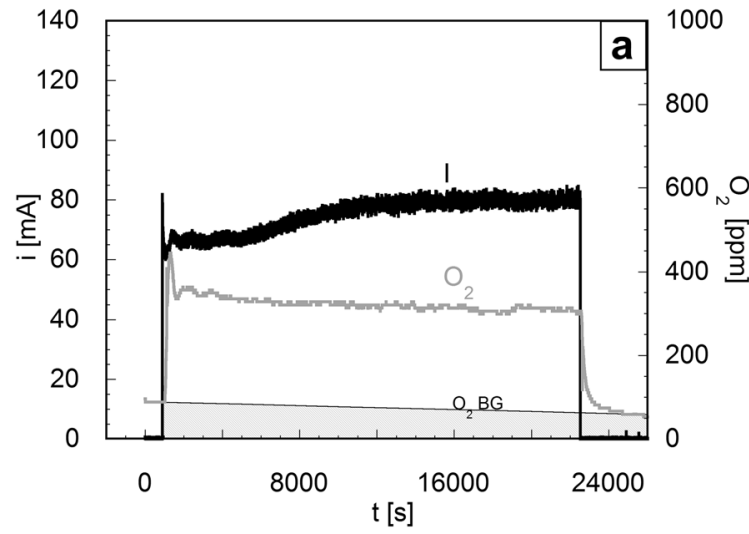

Fig. 8 Electrolysis of Fe\#15 composition, a trial (A), b trial (B). Cell voltage $3 \mathrm{~V}$; duration $360 \mathrm{~min}$, temperature: $1824 \mathrm{~K}( \pm 3)$, gas flow: $0.05 \mathrm{STP}^{3} \mathrm{~h}^{-1}$. The hachured area represents the thermally gener-

experimental duration. Difference in oxygen level was approximately $40 \mathrm{ppm}$ and, hence, not negligible.

The correspondence between current and oxygen was steady throughout the experimental duration (Fig. 8a, b). Signals of current and oxygen are consistent with the results from the linear scan voltammetry.

\subsection{Cross-section observations of the cell}

After cooling, the sample of trial (A) was cut into two pieces to show the arrangement of the cell during operation (Fig. 9). At the bottom of the crucible, the spherical iron deposit is clearly distinguishable from the electrolyte. Its diameter is around $3 \mathrm{~mm}$. The metallic part below leading into the cement is the $\mathrm{Pt} / \mathrm{Rh}$ cathode wire. In the electrolyte, two domains can be seen, one located in the top center of the cell showing amorphous characteristics and one with matt grainy texture in the bottom of the cell and in vicinity of the crucible. Only a little proportion of the electrolyte had drained through the hole in the bottom of the crucible and corroded to a small extent the cement. The main cavity in the cement is believed to be present before the trial and results from the preparation of the cement. The refractory itself shows a dark coloration but is not severely corroded.

The cell of trial (B) was broken into pieces and a small iron drop of spherical shape was recovered from the solidified electrolyte, weighing $170 \mathrm{mg}$. EDS analysis of the iron ball retrieved from the cell revealed an iron concentration of $77 \mathrm{wt} \%$ (average of 7 measurements), with the remaining elements within being $\mathrm{Pt}$ and $\mathrm{Rh}$, which derive from the cathode wire. A BSE image of the metal is shown in Fig. 10, its composition in Table 4. Few inclusion of the electrolyte and pure $\mathrm{SiO}_{2}$ (the latter up to $3 \mu \mathrm{m}$ ) were found within the deposit. The spherical shape of the metallic sample indicates its deposition at liquid state, as well as a high

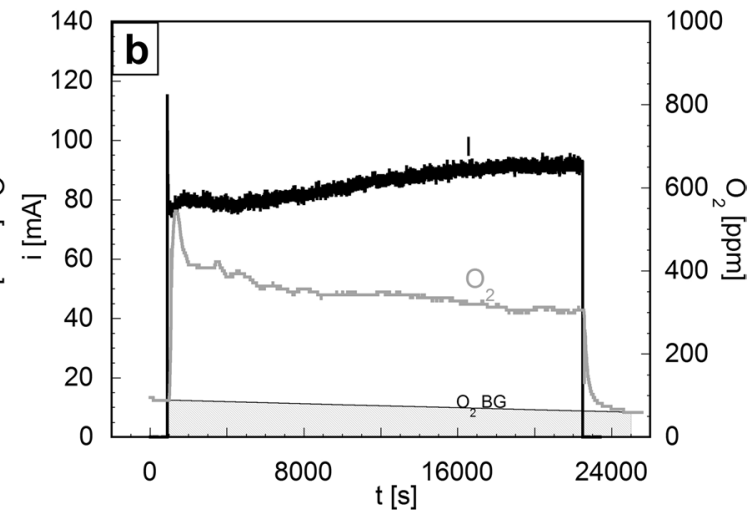

ated oxygen gas as derived from linear interpolation of the $\mathrm{O}_{2} \mathrm{ppm}$ level before and after the electrolysis

interfacial tension between metal and electrolyte. The keyparameters and important findings of the two trials are summarized in Table 5.

\section{Discussion}

The experimental results have shown that application of a cell voltage between the platinum electrodes dipped in the selected electrolyte causes faradaic reactions, one of them being indeed the reduction of iron ions into metal. The current and oxygen measurements can help to identify the other faradaic reactions that take place on the electrodes during the electrolysis experiments.

\subsection{Anodic electrochemical half reaction}

The acquired oxygen signals of the electrolysis experiments are corrected of the thermally generated oxygen released from the furnace (Fig. 7a). This component is estimated by interpolation between the oxygen values measured before and after voltage application. It is marked in the graphs with "O $\mathrm{O}_{2}$ BG." Subsequently, the acquired oxygen can be compared to the faradaic current, which is based on the assumption that the transferred charge is directly linked to the oxide anion discharged at the anode:

$2 \mathrm{O}^{2-} \rightarrow \mathrm{O}_{2}+4 \mathrm{e}^{-}$.

The fraction of the overall current involved in Reaction (12), from here on called $\# \mathrm{O}_{2}$, can be deduced by

$\# \mathrm{O}_{2}=\frac{\mathrm{O}_{2 \text { measured }}}{\mathrm{O}_{2 \text { current }}}$,

where $\mathrm{O}_{2}$ current is the rate of $\mathrm{molO}_{2} \mathrm{~s}^{-1}$ equivalent to the transferred charges during cell voltage application, following the stoichiometry of Reaction (12), and where $\mathrm{O}_{2}$ measured is 


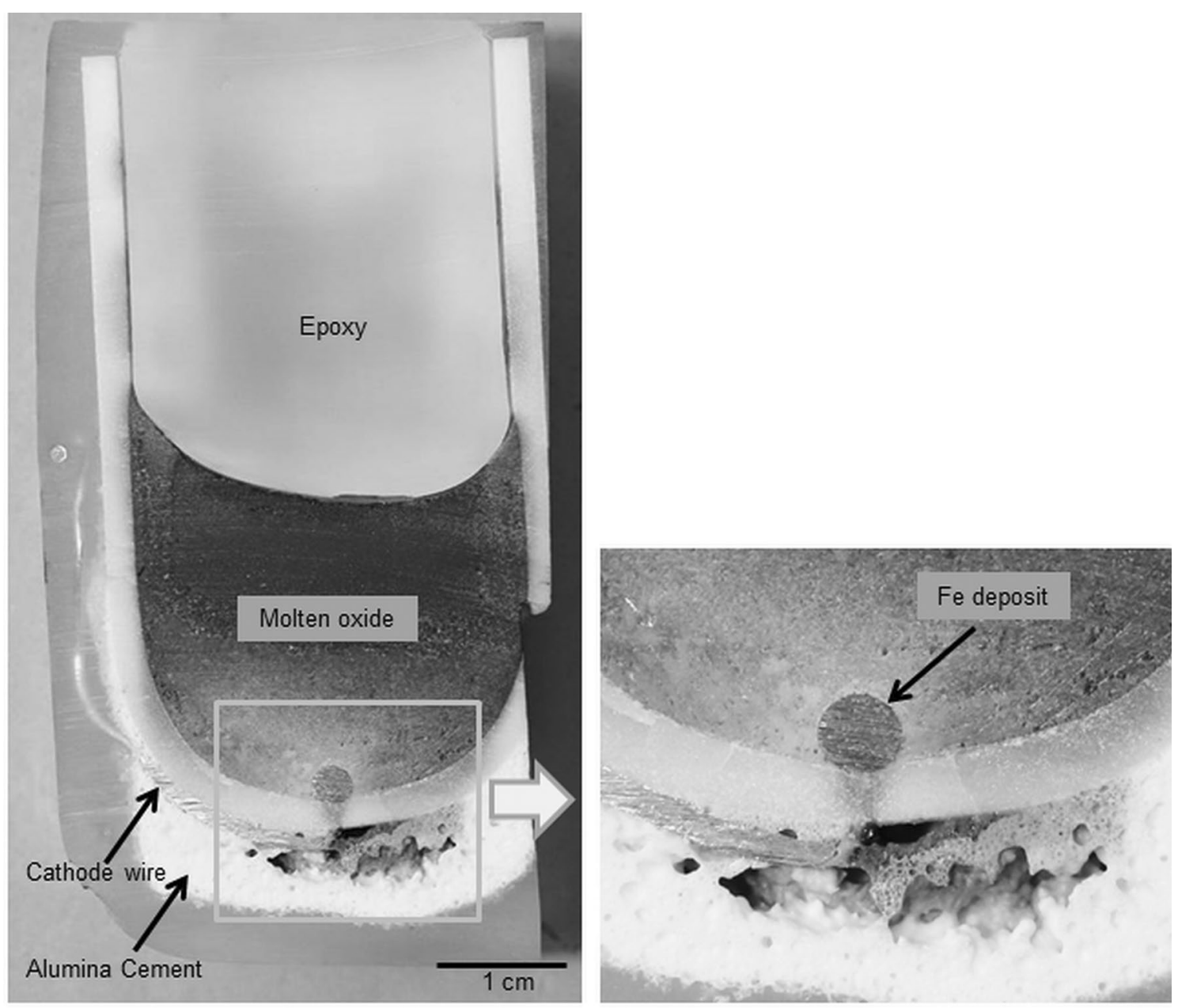

Fig. 9 Cross section of the electrolysis cell of trial (A). Experimental conditions: temperature: $1824 \mathrm{~K}( \pm 3)$, Ar gas flow: $0.048 \mathrm{STP}^{3} \mathrm{~h}^{-1}$, cell voltage: $3 \mathrm{~V}$, duration: $360 \mathrm{~min}$

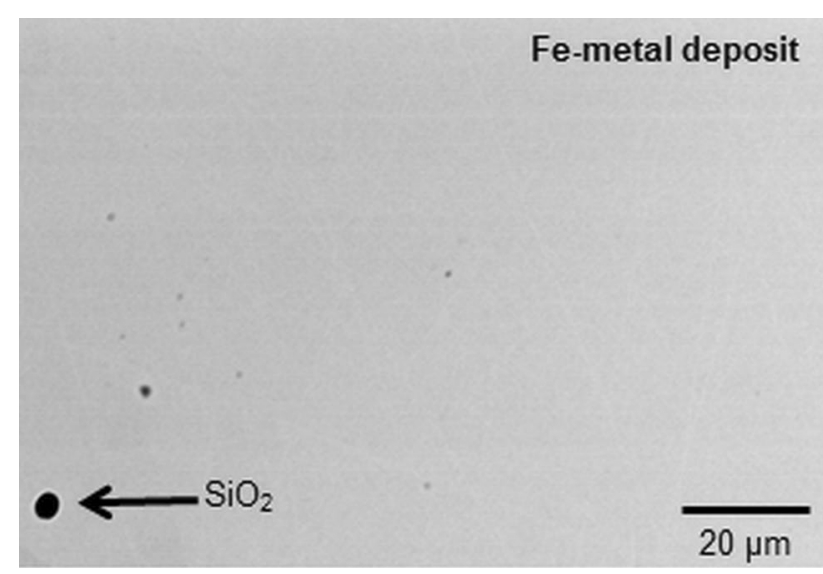

Fig. 10 BSE image of the iron deposit in trial (B). Accelerating voltage: $20 \mathrm{kV}$
Table 4 Average concentrations of the deposit produced in Fe\#15 determined by EDS

\begin{tabular}{lll}
\hline Element & $\begin{array}{l}\text { Average con- } \\
\text { centration (wt\%) }\end{array}$ & $\begin{array}{l}\text { STD (seven } \\
\text { measure- } \\
\text { ments) }\end{array}$ \\
\hline $\mathrm{Fe}$ & 77 & 0.2 \\
$\mathrm{Rh}$ & 7 & 0.2 \\
$\mathrm{Pt}$ & 16 & 0.1 \\
\hline
\end{tabular}

the experimentally measured rate of oxygen gas expressed with the same unit $\mathrm{molO}_{2} \mathrm{~s}^{-1}$.

$\# \mathrm{O}_{2}$ for the electrolysis of Fe\#15 experiments are displayed in Fig. 11. Integral values obtained from the whole duration of electrolysis trials (A) and (B) give a mean $\mathrm{\# O}_{2}$ of $76 \%$ according to Reaction (12). In these electrolysis experiments, $\# \mathrm{O}_{2}$ is decreasing with time to values as low 
Table 5 Experiments of electrolysis of iron oxides and summary of results

\begin{tabular}{|c|c|c|}
\hline $\begin{array}{l}\text { Electrolysis experi- } \\
\text { ments }\end{array}$ & (A) & (B) \\
\hline Cell voltage (V) & 3 & 3 \\
\hline $\begin{array}{l}\text { Electrolysis duration } \\
\text { (h) }\end{array}$ & 6 & 6 \\
\hline Electrolyte quantity (g) & 40 & 40 \\
\hline $\begin{array}{l}\text { Electrolyte composi- } \\
\text { tion }\end{array}$ & Fe\#15 & Fe\#15 \\
\hline $\begin{array}{l}\text { Mean cell current } \\
(\mathrm{mA})\end{array}$ & 75 & 85 \\
\hline $\begin{array}{l}\text { Mean oxygen concen- } \\
\text { tration }(\mathrm{ppm}) \text { in } 0.05 \\
\text { STP Ar m } \mathrm{h}^{-1}\end{array}$ & 321 & 348 \\
\hline Anodic efficiency (\%) & 74 & 78 \\
\hline $\begin{array}{l}\text { Amount of iron pro- } \\
\text { duced }(\mathrm{mg})\end{array}$ & 131 & Not measured \\
\hline $\begin{array}{l}\text { Cathodic efficiency } \\
(\%)\end{array}$ & 36 & Not measured \\
\hline $\begin{array}{l}\text { Visual appearance of } \\
\text { product }\end{array}$ & Round drop & Round drop \\
\hline
\end{tabular}

as nearly $60 \%$. The discrepancy can be partially explained by the electronic contribution which accounts for only for 9 of the $80 \mathrm{~mA}$ overall current. The remaining part of the anodic current can possibly be related to the chemical reaction of produced oxygen gas with a byproduct of the cathode process. The electrolysis of Fe\#0 showed the presence of aluminum metal, which determines the working potential to $\min 1.82 \mathrm{~V}$. In consequence, a potential this high allows as well production of $\mathrm{SiO}$ at the cathode following Reaction

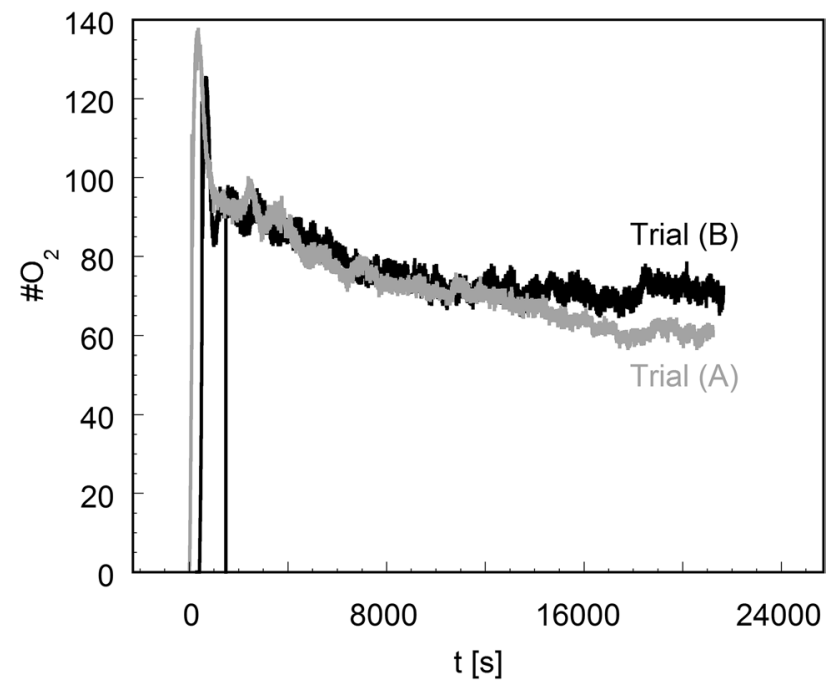

Fig. 11 Evolution of $\# \mathrm{O}_{2}$ with ongoing electrolysis of Fe\#15, cell voltage: $3 \mathrm{~V}$, temperature: $1824 \mathrm{~K}( \pm 3)$, gas flow: $0.05 \mathrm{STP} \mathrm{m}^{3} \mathrm{~h}^{-1}$, duration: $360 \mathrm{~min}$
(7). The evolved $\mathrm{SiO}$ then reacts with the produced oxygen gas at the anode to form $\mathrm{SiO}_{2}$ and is thus not measured.

The almost instantaneous production of oxygen gas under application of the cell voltage and the significant contribution of this reaction at the anode confirms that the electrolyte near the anode is in equilibrium with oxygen gas at atmospheric pressure. The concomitant production of iron is indicative that Reaction (11) is indeed processed during the experiment.

\subsection{Cathodic electrochemical half reaction}

As described in Sect. 5.4, the metal deposit of trial (A) was recovered and its mass quantified. According to the stoichiometry of Eq. (11), the metal mass represents $36 \%$ of the charges flown during trial (A) (equal to an average of $29 \mathrm{~mA}$ ), a value comparable to electrolysis done in similar experimental studies [6-8].

To explain the missing charge exchanged at the cathode, a charge balance was made. As described in Sect. 5.2, the electronic current explains $11 \%$ (or $9 \mathrm{~mA}$ ) of the current. Summed with the current attributed to iron metal production, $47 \%(38 \mathrm{~mA})$ of the charge transfer is at this point identified. The missing 53\% (42 mA) could be to a small part related to an incomplete recovery of the produced metal. Most presumably, the complement is related to the faradaic reaction of the electrolyte compounds. Indeed, the Fe\#0 experiments indicate that the cathode was enough polarized to reduce alumina which is the less reducible compound. The corresponding current was $15 \mathrm{~mA}$ with Fe\#0, which is not enough to account for the remaining charges in Fe\#15. This current could be amplified by the ionic conductivity enhancement due to iron oxide introduction. The conductivities of Fe\#0 and Fe\#15 have been estimated and show that iron oxide has amplified the conductivities by a factor three, cf. Table 6. Application of this factor onto the charge transfer related to the constituents of the electrolyte could then explain the elevated value of the measured current.

\section{Conclusion}

The production of liquid iron by direct application of electric energy to decompose iron oxides represents a major opportunity to propose radically shorter steel producing routes

Table 6 Estimated ionic conductivities of the electrolytes

\begin{tabular}{ll}
\hline & $\begin{array}{l}\text { At 1823 K } \\
\text { conductivity } \\
\left(\mathrm{S} \mathrm{cm}^{-1}\right)\end{array}$ \\
\hline Fe\#0 & $0.03[29]$ \\
Fe\#15 & $0.09[30]$ \\
\hline
\end{tabular}


compared to conventional ones. The implementation of this reaction in a controlled way and at steady state has been carried out with a small-scale experimental device at $1823 \mathrm{~K}$. An electrolyte composed of molten oxides has been derived, from thermodynamic considerations, to flow electric current ionically and to overcome the problem of the multiple valence states of the oxidized iron element. The production of liquid iron samples has been accomplished relying on the sole application an electrical voltage surpassing the minimum thermodynamic requirement. The faradaic character of the cathodic reaction was checked by following the accompanying anodic oxygen gas evolution. Afterwards, the observation and analysis of the samples confirmed the reduction of iron into metal. The current chosen was large enough to produce macroscopic iron samples during the time of the experiment and to evolve oxygen gas at a rate significantly higher than the thermally generated oxygen; however, the corresponding voltages were exceeding the thermodynamic threshold of decomposition of constituents of the electrolyte.

Acknowledgements The authors wish to acknowledge the French Agency for the Environment and Energy Management (ADEME) for the financial support. We are grateful to Mr Jean Lehmann for the numerous discussions and the valuable suggestions during the preparation of this study.

Open Access This article is distributed under the terms of the Creative Commons Attribution 4.0 International License (http://creativecommons.org/licenses/by/4.0/), which permits unrestricted use, distribution, and reproduction in any medium, provided you give appropriate credit to the original author(s) and the source, provide a link to the Creative Commons license, and indicate if changes were made.

\section{References}

1. Kundak M, Lazić L, Črnko J (2009) $\mathrm{CO}_{2}$ emissions in the steel industry. Metallurgija 48:193-197

2. Birat J-P, Hanrot F, Danloy G (2003) $\mathrm{CO}_{2}$ mitigation technologies in the steel industry: a benchmarking study based on process calculations. Stahl Eisen 123:69-72

3. Birat J-P, Borlée J, Lavelaine H, Negro P, Meijer K, Van der Stel J, Sikström (2012) ULCOS program: an update in 2012 SCANMET 4. In: Proceedings of the 4th international congress on process development in iron and steelmaking. Lulea, Sweden, pp 35-45

4. Hashkin LA, Colson RO, Lindstrom DJ, Lewis RH, Semkow KW (1992) Electrolytic smelting of lunar rock for oxygen, iron and silicon. In: Proceedings of the 2 nd conference on lunar bases and space activities. Houston, USA, pp 411-422

5. Sadoway DR (1995) New opportunities for metals extraction and waste treatment by electrochemical processing in molten salts. $\mathrm{J}$ Mater Res 10:487-492

6. Kim H, Paramore JD, Allanore A, Sadoway DR (2011) Electrolysis of iron oxide with an iridium anode: the role of optical basicity. J Electrochem Soc 158:E101-E105

7. Allanore A, Yin L, Sadoway DR (2013) A new anode material for oxygen evolution in molten oxide electrolysis. Nature 497:353-357
8. Sirk AHC, Sadoway DR, Sibille L (2010) Direct electrolysis of molten lunar regolith for the production of oxygen and metals on the moon. ECS Trans 28:367-373

9. Allanore A (2015) Features and challenges of molten oxide electrolytes for metal extraction. J Electrochem Soc 162:E13-E22

10. Thonstad J, Fellner P, Haarberg GM, Híveš J, Kvande H, Sterten A (2001) Aluminium electrolysis: fundamentals of the Hall-Héroult process, 3rd edn. Verlag, Düsseldorf

11. Kusano K, Rio, Sano K (1970) The solubility of oxygen in 5-Iron. Trans Iron Steel Inst Jpn 10:78-82

12. Wriedt HA (1991) The Fe-O (Iron-Oxygen) system. J Phase Equilib 12:170-200

13. Poveromo JJ (1999) Iron ores. In: Wakelin DH (ed) Making, shaping and treating of steel: ironmaking volume, 11th edn. AISE Steel Foundation, Pittsburgh, pp 547-642

14. USGS (2016) http://minerals.usgs.gov/minerals/pubs/commodity/ iron_ore/. Accessed 16 Aug 2016

15. Crouch AG, Hay KA, Pascoe RT (1971) Magnetite-haematiteliquid equilibrium conditions at oxygen pressures up to 53 bar. Nat Phys Sci 234:132-133

16. Darken LS, Gurry RW (1946) The system iron-oxygen. II Equilibrium and thermodynamics of liquid oxide and other phases. $\mathrm{J}$ Am Chem Soc 68:798-816

17. Barati M, Coley KS (2006) Electrical and electronic conductivity of $\mathrm{CaO}-\mathrm{SiO}_{2}-\mathrm{FeO}_{\mathrm{x}}$ at various oxygen potentials: Part II. Mechanism and a model of electronic conduction. Metall Mater Trans B 37B:51-60

18. Sundman B (1991) An assessment of the Fe-O system. J Phase Equilib 12:127-140

19. Turkdogan ET (1983) The physicochemical properties of molten electrolytes and glasses. The Metals Society, Carlton House Terrace

20. Mysen BO, Seifert F, Virgo DO (1980) Structure and redox equilibria of iron-bearing silicate melts. Am Mineral 65:867-884

21. Mills KC (1993) The influence of structure on the physico-chemical properties of electrolytes. Iron Steel Inst Jpn Int 33:148-155

22. Ottonello G (2001) Thermodynamic constraints arising from the polymeric approach to silicate electrolytes: The system $\mathrm{CaO}$ $\mathrm{FeO}-\mathrm{SiO}_{2}$ as an example. J Non-Cryst Solids 282:72-85

23. Gitzen WH (1970) Alumina as a ceramic material. The American Ceramic Society, Westerville

24. Osborn EF, Muan A (1960) Phase equilibrium diagrams of oxide systems. Ceramic Society with the Edward Orton Jr Foundation, Westerville

25. Gatellier C, Gaye H, Lehmann J, Zbaczyniak Y (1992) Des outils thermodynamiques pour la maîtrise des réactions métal-laitier et le contrôle inclusionnaire des aciers. Rev Métall 89:887-888

26. Barin I (2004) Thermochemical data of pure substances. Wiley$\mathrm{VCH}$, New York

27. Di Martino J, Rapin C, Berthod P, Podor R, Steinmetz P (2004) Corrosion of metals and alloys in molten glasses: Part 1 glass electrochemical properties and pure metal $(\mathrm{Fe}, \mathrm{Co}, \mathrm{Ni}, \mathrm{Cr})$ behaviours. Corros Sci 46:1849-1864

28. Okamoto H (1993) Phase diagrams of binary iron alloys, Monograph Series on Alloy ASM International ${ }^{\circledR}$, Materials Park, Ohio

29. Downing JH, Urban L (1966) Electrical conduction in submerged arc-furnaces. J Met 18:337-344

30. Georgalli GA, Eksteen JJ, Bezuidenhout R, van Beek B, Goff T (2009) Towards electrode immersion control on Lonmin's no. 1 circular furnace. J S Afr Inst Min Metall 109:53-64 